\title{
Susan Lynn Williams: the Life of an Exceptional Scholar, Leader, and Friend (1951-2018)
}

\author{
William C. Dennison ${ }^{1}$ (D) Matthew E. S. Bracken ${ }^{2} \cdot$ Maria Brown $^{3}$ • John F. Bruno ${ }^{4}$ - James T. Carlton ${ }^{5}$. \\ Robert C. Carpenter ${ }^{6} \cdot$ Tim J. B. Carruthers $^{7} \cdot$ Megan N. Dethier $^{8} \cdot$ Carlos M. Duarte $^{9} \cdot$ Thomas R. Fisher $^{1}$. \\ James W. Fourqurean ${ }^{10}$. Richard K. Grosberg ${ }^{11}$ • Leila J. Hamdan ${ }^{12} \cdot$ Ken L. Heck Jr ${ }^{13}$. Dan J. Howard ${ }^{14}$. \\ A. Randall Hughes ${ }^{15} \cdot$ Brent B. Hughes $^{16} \cdot$ Gary A. Kendrick $^{17} \cdot$ W. Judson Kenworthy ${ }^{18} \cdot$ Frank Mars $^{19}$. \\ C. Peter McRoy ${ }^{20}$. Rosamond L. Naylor ${ }^{21}$ • Bruce Nyden ${ }^{22}$ • John C. Ogden ${ }^{23}$. Suzanne Olyarnik ${ }^{24}$. Robert J. Orth ${ }^{25}$. \\ Frederick T. Short ${ }^{26}$. Cascade J. B. Sorte ${ }^{2}$. John J. Stachowicz ${ }^{27}$. Donald R. Strong ${ }^{28} \cdot$ Christine Sur $^{28}$. \\ Michelle Waycott ${ }^{29}$
}

Received: 5 March 2020 / Revised: 9 November 2020 / Accepted: 9 December 2020 / Published online: 15 January 2021

(C) The Author(s) 2021

\begin{abstract}
Susan Lynn Williams (1951-2018) was an exceptional marine ecologist whose research focused broadly on the ecology of benthic nearshore environments dominated by seagrasses, seaweeds, and coral reefs. She took an empirical approach founded in techniques of physiological ecology. Susan was committed to applying her research results to ocean management through outreach to decision-makers and resource managers. Susan's career included research throughout the USA in tropical, temperate, and polar regions, but she specialized in tropical marine ecology. Susan's scholarship, leadership, and friendship touched many people, leading to this multi-authored paper. Susan's scholarship was multi-faceted, and she excelled in scientific discovery, integration of scientific results, application of science for conservation, and teaching, especially as a mentor to undergraduate and graduate students and postdoctoral scholars. Susan served in a variety of leadership positions throughout her career. She embodied all facets of leadership; leading by example, listening to others, committing to the "long haul," maintaining trust, and creating a platform for all to shine. Susan was an important role model for women in science. Susan was also a loyal friend, maintaining friendships for many decades. Susan loved cooking and entertaining with friends. This paper provides an overview of the accomplishments of Susan in the broad categories of scholarship, leadership, and friendship.
\end{abstract}

Keywords Seagrass $\cdot$ Macroalgae $\cdot$ Invasive species $\cdot$ Public engagement

\section{Introduction}

Susan William's academic career began at the University of Michigan. She started out in an engineering program, but switched to biology when she discovered her true calling, graduating as a Biology major with a Bachelor of Science degree in 1972. Susan moved to Fairbanks, Alaska, where she conducted her Master's research at the Institute of Marine Science, University of Alaska. Her research was supported by the

Communicated by Kenneth Dunton

William C. Dennison

dennison@umces.edu

Extended author information available on the last page of the article
National Science Foundation's Seagrass Ecosystems Study, headed up by her advisor C. Peter McRoy. Susan conducted research in Alaska, Texas, and at the West Indies Laboratory, Fairleigh Dickinson University, where she worked with John Ogden. Susan's first scientific publication was about drift algae in Texas (Cowper 1977). Susan graduated in 1977 from the University of Alaska and moved to Washington, D.C., where she worked with Walter Adey at the Smithsonian Institution and enrolled in the Marine Environmental Estuarine Science program at the University of Maryland. Susan's PhD advisor was Tom Fisher who provided her with access to a mass spectrometer and collaborated with her following her dissertation on Hydrolab and Aquarius underwater habitat missions, Fig. 1.

Following her Ph.D., Susan was an Assistant Research Professor at Stony Brook University (1982-1984) before she joined NOAA's National Undersea Research Program, based 


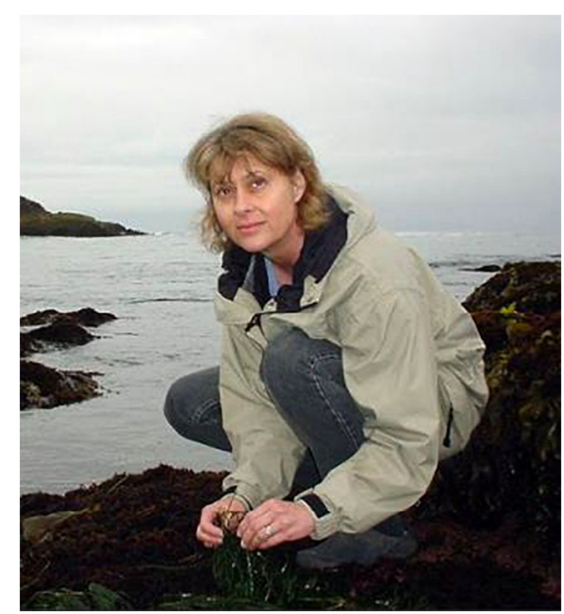

Fig. 1 Susan Williams (1951-2018) (photo provided by UC Davis)

at the Fairleigh Dickinson's West Indies Laboratory in St. Croix, US Virgin Islands. Susan married Bruce Nyden in 1986 in St. Croix, and they remained married until her death. She joined the research faculty at Friday Harbor Laboratories, University of Washington (1986-1990), and then moved to San Diego State University where she was based from 1990 to 2000. Susan then took on the Directorship of the Bodega Marine Laboratory, University of California, Davis, and remained an active faculty member there. Susan's research and teaching showed no signs of slowing. True to her calling as an educator, Susan was driving with a car full of live marine organisms from Bodega Bay to deliver a lecture at UC Davis when her life was tragically ended in 2018.

Over the course of her career, Susan received numerous honors and awards including a Fulbright Award (Universitas Hasanuddin), Riser Distinguished Lecturer (University of California Santa Cruz), Distinguished Service Award (Coastal \& Estuarine Research Federation), Distinguished Public Scholarly Service Award (UC Davis), Outstanding Mentor (Consortium for Women in Research; UC Davis), Wiese Distinguished Lecturer (Dauphin Island Sea Lab), Fellow (American Association for the Advancement of Science), Fellow (California Academy of Sciences), Aldo Leopold Fellow in Environmental Leadership, Fellow (Japan Society for the Promotion of Science), Outstanding Biology Faculty (San Diego State University), and Outstanding Student in Oceanography (University of Alaska). Susan was selected for these awards at a diversity of institutions, not because she sought them, rather because she was an incredibly hard working, caring, and deeply committed scientist who served as an amazing role model to young women scientists.

Susan excelled at all aspects of academia, including obtaining research funding, obtaining science infrastructure funding, presenting at scientific conferences, teaching and mentoring, publishing peer reviewed papers (over 100), reviewing papers (50+ journals), and delivering numerous public talks and media interactions.
Susan conducted a large portion of her research underwater (Fig. 2). She helped pioneer the generation of researchers who made observations and conducted experiments in subtidal marine habitats. Susan was an expert SCUBA diver, and was inducted posthumously into the Women's Divers Hall of Fame. She was an aquanaut four times, living in an underwater habitat. Susan was certified as a SCUBA diver for 45 years, beginning in 1972. Susan continued to conduct underwater research projects, most recently focused on understanding the drivers of success in restoring coral habitats (e.g., Williams et al. 2017), in Indonesia. Susan would dive for pleasure as well as for research. Her former mentor John Ogden wrote the following: "Several years ago, Nancy [Ogden] and I joined her, Bruce [Nyden] and others on a 10day coral reef diving cruise in the Lesser Sunda Islands of Indonesia on a beautiful traditional Bugis phenisi schooner. Susan was energetic and studious, diving four times a day and building a long species list of reef fishes and inverts. But I remember most her joyous smile when she was among the Indonesian crew and villagers that we visited. She found something personal and magical in the people and the culture."

Susan loved field work, and was not one to complain about being uncomfortable. One of her former students, Amanda Newsom, told the following story: "Early one dark, stormy morning in (I think) late fall, when the lab was mostly silent and empty still, I was coming in and saw this petite form marching down the hall towards me in a bright yellow rain slicker, boots, and coveralls. She was weighed down with equipment, and she looked up at me as we drew closer. There was an enormous grin on her face and her eyes were sparkling in a way I hadn't seen before. She announced, 'I'm going out ... to do field work!'."

\section{Scholarship}

Susan Lynn Williams was a scientist who embodied the ethos of conducting original research and making that research relevant for the betterment of society. In a seminal work,

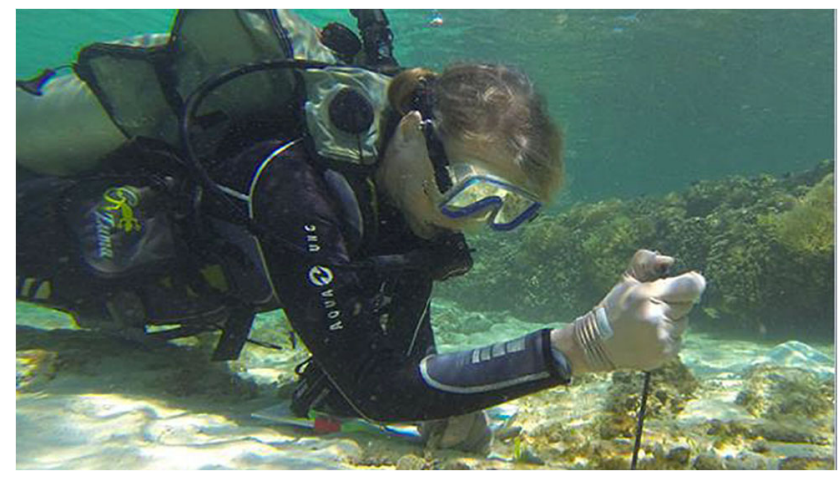

Fig. 2 Susan Williams underwater (photo credit: Dale Trockel) 
Boyer (1990) defined scholarship in four categories: discovery, integration, application, and teaching. Susan Williams excelled in all four categories, each described in the following sections.

Discovery Susan actively conducted original research in both the laboratory and the field, and she was instrumental in making unique discoveries. Susan represented the generational shift to conducting much of her field research underwater; her predecessors were largely restricted to the intertidal zone or the laboratory. Susan did conduct intertidal and laboratory research, but she also was an accomplished SCUBA diver, and she spent endless hours underwater in all sorts of conditions. Susan's underwater observations backed up with laboratory studies led her to challenge existing paradigms throughout her career.

Susan used radioisotopes in her Masters' research to measure carbon uptake by seagrasses (Williams and McRoy 1982) and then used stable isotopes to track the uptake of sediment nutrients by coenocytic green algae (Williams 1984; Williams and Fisher 1985). Coenocytic green algae are giant single cells with multiple nuclei that move via cytoplasmic streaming. Susan's PhD research upended the paradigm that algae absorbed water column nutrients exclusively. Early on, Susan recognized the importance of seagrass detritus in marine food webs (e.g., Suchanek et al. 1984) as well as the importance of tropical seagrass as a food source for megaherbivores (e.g., Thayer et al. 1984; Williams 1988a). During and immediately after her dissertation research, Susan studied the deepwater environments off St. Croix (e.g., Williams et al. 1985; Williams 1988b, 1990; Williams and Carpenter 1988), which required extensive SCUBA diving combined with experimental manipulations and state-ofthe-art scientific techniques. Susan compared the circadian rhythms of a seagrass and a green alga using in situ light manipulations (Williams and Dennison 1990). Susan began and maintained a long and productive collaboration with Bob Carpenter, and they co-authored papers on coral reef algal turfs over several decades (e.g., Williams and Carpenter 1988, 1990; Carpenter and Williams 1993, 2007).

Moving to the west coast, Susan began looking at the genetic diversity and structure of seagrasses (e.g., Williams and Davis 1996; Williams and Orth 1998; Williams 2001). She was one of the first scientists to recognize the emergence of Ruppia in disturbed seagrass communities (e.g., Johnson et al. 2003). But then Susan's research added a new component, studying the effects of introduced species, starting with studies of an Asian mussel in San Diego Bay (Reusch and Williams 1999), followed by studies of the invasion of a marine macroalga, Caulerpa, in southern California (e.g., Williams and Grosholz 2002; Williams and Schroeder 2004). Susan became an invasive species polymath, publishing over twenty papers on aspects of (a) invasive species and native seagrass interactions, (b) post-invasion management, (c) invasion vectors and their management, (d) invasions and climate change, and (e) synthesizing ecological aspects of invasive species (Williams and Smith, 2007).

Integration Susan was a key member of the Seagrass Trajectories Working Group at the National Center for Ecological Analysis and Synthesis (NCEAS). In addition to Susan's important individual contribution, as an advocate of women in science, she also recruited two young female University of California graduate students, Randall Hughes and Suzanne Olyarnik to join the working group. Several seminal papers resulted from this synthesis effort, including a Bioscience paper "A global crisis for seagrass ecosystems" (Orth et al. 2006) and a Proceedings of the National Academy of Sciences paper "Accelerating loss of seagrasses across the globe threatens coastal ecosystems" (Waycott et al. 2009). Each of these papers has received over 2000 citations and represent the most cited seagrass papers in the world. At the special session as a tribute to Susan Williams at the Coastal and Estuarine Research Federation conference in 2019, almost all of Susan's co-authors from this NCEAS project attended, a testament to her lasting impact.

Susan did comprehensive reviews of various topics throughout her career, including the impact of invasive species (Lodge et al. 2006; Williams and Grosholz 2008; Ojaveer et al. 2018), the impact of invasive species on seagrasses (Williams 2007), trophic transfers from seagrasses (Heck Jr et al. 2008), and plastics in seafood (Rochman et al. 2015).

Application US Congressman Jared Huffman submitted a tribute to Susan to the Congressional Record that included the following statements:

Dr. Williams' scientific research on coastal ecology and her activism surrounding the expansion of marine sanctuaries have left an indelible impact on the world. Throughout her career, Dr. Williams' research underlined the connection between the health of oceans and the communities surrounding them. Her work on the ecology of nearshore marine ecosystems, seagrass, coral reefs, and invasive species helped illustrate the impact of warming oceans on coastal environments and yielded strategies for mitigating those impacts. Her work was heralded by the international scientific community, and provided the foundation for critical changes to state and federal policies addressing the management of coastal environments. Dr. Williams became a valued advisor for state and federal officials seeking to protect the California coast. Nowhere was this more apparent than through her work in significantly expanding two national marine sanctuaries off the coast of Northern California: the Cordell Bank National Marine Sanctuary, and the Gulf of the Farallones, now 
known as the Greater Farallones National Marine Sanctuary. Both sanctuary boundary expansions were proposed in legislation in 2005, and were ultimately expanded to more than twice their original size by the Obama administration in 2015. Throughout that ten-year process, Dr. Williams was the driving force that propelled the policy forward. (162 Cong. Rec. E737 2018)

Susan made multiple trips to Sacramento, CA, and Washington, D.C., to provide testimony or to brief congressional delegations. Susan worked tirelessly to provide the scientific basis for the expansion of marine sanctuaries and she often made these trips to Washington, D.C., at her own expense while juggling her many teaching, research and administrative duties. Susan also made the case for the inclusion of biodiversity in habitat restoration (Hughes et al. 2017) and she kept working to influence management and policy, even when she sometimes felt as though she was "Shouting into a hurricane".

Susan's latest research interests and science application efforts were in Indonesia, and she was deeply involved in a fruitful collaboration with Indonesian scientists and the Mars Incorporated's coral reef restoration program. This experience in the Coral Triangle, a global biodiversity hot spot, caused Susan to reevaluate her priorities and shift her perspectives (e.g., Williams 2013). Susan made multiple trips to Indonesia, often taking graduate students along with her and conducting outreach (e.g., Sur et al. 2018) in addition to focusing on capacity building and research. Former student Holly Hanson Henderson said the following: "I carry the lessons and approach to science that I learned from Susan with me in my work every day. Susan was unwavering in her belief that science needs to be thoughtful and rigorous, and that it is our obligation as scientists to go out into the world to make a difference." Susan wrote about how species richness accelerates marine ecosystem restoration in the coral triangle (Williams et al. 2017). Susan became the lead scientific advisor to Mars on a large-scale coral restoration project, documented in a paper published posthumously (Williams et al. 2019). She also helped design a second trial, which is still ongoing and is the world's largest controlled coral reef restoration experiment, scheduled to finish in early 2021 .

\section{Teaching}

Susan's former students were polled and they generated a word cloud to describe her. Words to describe Susan included the following: brilliant, sparkling, incisive, creative, trailblazer, generous, influential, passionate, direct, genuine, diplomatic, frank, tough, human, supportive, impactful, incredible, and honest (Fig. 3).

Bobby Espinoza said this about Susan's mentorship: "All along, Susan supported me, as a person. Most other advisors

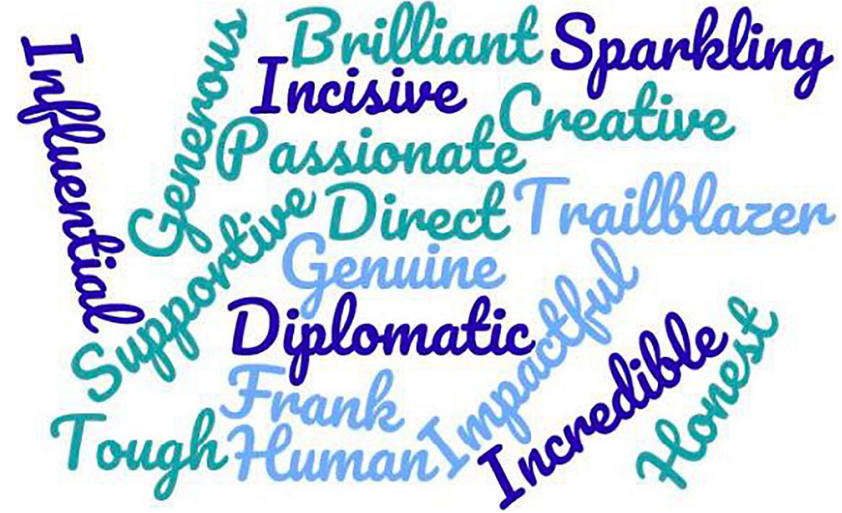

Fig. 3 Word cloud to describe Susan Williams generated by her former students

would have abandoned me and my project soon after it morphed into something so distant from their own research interests. Not Susan. And she has continued to support me throughout my career." Bengt Allen said the following: "As I look back over the past 20 years since I left her lab, I've more or less been successful by continuing to do all of the things she had me doing as a new graduate student."

Amanda Newsom said this about Susan's impact: “I don't think I would have pursued or merited the work I do now without that shift Susan cultivated in me towards valuing myself and my truth. As a trailblazer for women in our field, Susan had to learn how to value herself in order to be the empowering presence she became. I think her influence was what finally made me understand my own worth as a professional. She demanded that I develop a thicker skin and a higher opinion of myself, which is a difficult thing to do, but I think she accomplished it with many of her students."

Randall Hughes said that the Ralph Waldo Emerson quote fit Susan's mentorship; "Our chief want in life is somebody who will make us do what we can." In that vein, Susan was the advisor for the following graduate students: Lucina Hwang, Seth Yarish, and Eric Telemaque (Stony Brook Univ.); Mary Ruckelshaus (Univ. Washington); Michelle Chow, Tim Lu, Bobby Espinoza, Russ DiFioni, Chris Davis, Donna Ross, Patrick Ewanchuk, Amy Sewell, Alex Cheroske, Bengt Allen, Holly Hanson Henderson, Megan Cooper, and Carolyn Lieberman (San Diego State Univ.); and Laura Rodriguez, Heidi Weiskel, Cascade Sorte, Amanda Newsom, Amber Szoboszlai, Grace Ha, and Katie DuBois (Univ. California, Davis). But this list is far from complete-Susan was often a "drive-by" advisor who provided many more students and postdocs with input and career advice. Susan provided important input to Matthew Bracken, Jeffrey Wright, Christopher Harley, Raquel MuñizSalazar, Brendon Larson, Cynthia Hays, Randall Hughes, Jae Pasari, Laura Reynolds, and Brent Hughes (Univ. of California, Davis) and Florence Thomas, Thorsten Reusch, Jorge Terrados, and Terrie Klinger (San Diego State Univ.). 
Susan also provided K-12, undergraduate, and graduate mentoring to numerous students through programs like the Research Experiences for Undergraduates, National Science Foundation Graduate K-12 program (CAMEOS at University of California, Davis).

Susan taught a wide diversity of courses over her career, including Seagrass Biology and Ecology, Marine Ecology, Biological Invasions, Climate Change in the Nearshore Ocean, Marine Primary Producer Physiological Ecology, Life in the Sea, Principles of Ecology, Marine Environmental Issues, Phycology, Ecology and the Environment, Evolution and Ecology, Aquatic Ecology, Biogeochemistry of Coral Reefs, Algology, Estuarine Botany, Advanced Phycology, Ecology of Coral Reefs, and Tropical Coastal Marine Ecology. Susan developed numerous syllabi, lectures, and laboratories for individually designed courses. Susan even co-authored a paper that outlines ways for research scientists to more actively participate in K-12 education (e.g., Komoroske et al. 2015).

\section{Leadership}

Susan held a variety of leadership positions over her long career. Early in her career, Susan served as the Science Director of NOAA's Undersea Research Program, based in the US Virgin Islands (1984-1986). In her mid-career, Susan was the Director of the Coastal \& Marine Institute at San Diego State University (1993-2000). Later in her career, Susan was the Director of the Bodega Marine Laboratory (2000-2009). Susan also served as the President of the Coastal and Estuarine Research Federation (2009-2011), an international scientific organization with over 1500 members.

Susan participated in the Aldo Leopold leadership training program, along with Rosamond Naylor and others. Susan excelled in the five Leopold leadership attributes:

1. Leading by example, demonstrating personal leadership. Susan was usually the hardest working member of any team. Her former student Cascade Sorte said the following: "Have any of you heard the suggestion that to impress your supervisor, you should start work before them and/or stay at work after them? Well, that is literally impossible when you work with Susan. Her work ethic and influence are incredible." Susan never asked others to do what she would not do herself. She conducted field work in all conditions and never shirked the drudgery of clean up or breaking down experiments. Susan lived her life in an exemplary manner, always conscious of those around her who had less privileged lives.

2. Listening to colleagues, students and community members. Susan was a great listener. She walked into a room to say "There you are", rather than "Here I am." She was respectful to others, and was someone who took the time to listen to all the people around her. She had an open door policy and various students, faculty, and staff often took the opportunity to use Susan as a sounding board and a friendly ear.

3. Committing to the "long haul." Susan was a consistent and committed scientist. She spent years and decades on various projects, resulting in some seminal publications that will be difficult to replicate. For example, Susan published a major work in Ecological Monographs that stemmed from hundreds of hours underwater (Williams 1990) that was the culmination of years of effort. Brent Hughes described the persistence that Susan encouraged after multiple unsuccessful attempts to obtain funding for a seagrass restoration project in Elkhorn Slough. The ultimately funded and successful restoration project is now known as "Susan's Garden."

4. Developing and holding trust. Susan was a trusted confidant to many people. She was direct and honest at all times. Her former student Amber Szoboszlai said the following: "Of all the professors I met with from California to Washington, Susan was the only one who was direct and honest about her assessment of my application. Her recommendation illuminated a pathway to grad school for students traditionally seen as deficient in their requirements. Although Susan's honesty was at times hard to receive, her transparency and willingness to "tell it like it is' were genuine and impactful for many of her students."

5. Creating a platform for all to shine. Susan was the best audience. Leila Hamdan said, "Susan was always sitting front and center and nodding encouragingly." Former student Holly Hanson Henderson said the following about Susan's cohort of graduate students: "We supported each other. We bought swim team coats to wear after diving and had them embroidered with 'Team Williams'." Susan was painfully aware of the challenges of being a woman marine scientist. Her former student Megan Johnson Cooper said that Susan told her the following: "Being a female scientist is important. We often need to be stronger than the men in the room."

\section{Friendship}

Science is often thought about in terms of ideas, data, and hypotheses. But science is performed by humans, and this dimension of science is just as important as the data and theories. When Susan's friends and colleagues learned of her 
passing, our collective sense of loss was keenly felt. Many of us appreciated Susan and her humor, humility, care, values, and her wonderful smile.

Susan's career was largely based at semi-remote field laboratories. One of the things that occur at field laboratories is the establishment of intense personal relationships. People working at field laboratories tend to both work and socialize together. In addition, field trips can be strenuous experiences that test people's fortitude, and this leads to a realization of your abilities and the abilities of your colleagues. Thus, Susan's personal relationships with colleagues were often deeper than typical academic relationships.

Susan accumulated many friends and she maintained some four and five decade friendships. People like Bob and Hedy Carpenter, Bill Dennison, Jud Kenworthy, John and Nancy Ogden, and Fred Short were long-time friends and colleagues. For Susan, the friends that she made along her life journey enriched her life, along with her family, in particular her sister Holly, brother-in-law Art, and niece Kaitlin.

Susan loved to cook and share meals with friends. Her former student Alex Cheroske said this about the impact of her cooking: "I tell people that by the end of my first year of grad school, I had a subscription to the journal Ecology and Bon Appetit magazine. Susan was a mentor both in the field and in the kitchen and I took copious notes while I was observing her work in both realms."

Bengt Allen said the following: "Personally, aside from providing continued support and guidance long after I graduated from her lab, the other major impact Susan had on my life was through her cooking. Susan used to have lab parties at her house once a semester or so, where she would cook just amazing food. My then girlfriend (now wife of almost 20 years) and I would marvel at her custom kitchen with 6-burner stove, copper pots, and built-in cookbook library. Her passion for cooking as a vocation outside of work was contagious - we regularly cook using recipes that Susan provided us for some of our favorite dishes we first tried at her house (e.g., vodka pasta with prosciutto, creamy chicken jalapeno quesadillas, and habanero salsa)."

Cascade Sorte wrote the following: "This empowerment and blurring of the lines of work and 'life' - two of the messages that I think Susan personifies - are also messages that can help diversify our field, by keeping people like myself who are deeply committed to both family and science - in the field. When, just over one month after starting my graduate work in her lab, I announced to Susan that I was expecting, she could not have responded more positively. Not once - not one single time - has Susan seemed to question my scientific ambition or ability to juggle my family and work responsibilities."

\section{Conclusion}

Susan left a lasting impression on the people she encountered throughout her life, as was evidenced in the outpouring of feelings and thoughts stimulated by her death. She was Roberta Marinelli's "North Star" and Tessa Hill said that Susan was "A Whole Person". Susan's former students and mentees said that Susan taught them to be "Big and Brave" and commented on the sticky note she had in her office that said "You Can Do It". Susan Williams created a legacy of impacts through her scholarship, leadership and friendship.

Mary Oliver (1935-2019) wrote a wonderful poem "Pipefish" which was read by Susan's former mentee A. Randall Hughes at her memorial at U.C. Davis. This poem is a fitting tribute to Susan:

In the green and purple weeds called Zostera, loosely swinging in the shallows,

I waded, I reached my hands in that most human of gestures-to find,

to see, to hold whatever it is that's there-and what came up

wasn't much but it glittered and struggled, and it had eyes, and a body

like a wand, it had pouting lips. No longer, all of it,

than any of my fingers, it wanted away from my strangeness, it wanted

to go back into that waving forest so quick and wet. I forget

when this happened, how many years ago I opened my hands-like a promise

I would keep my whole life, and have-and let it go. I tell you this

in case you have yet to wade into the green and purple shallows where the diminutive

pipefish wants to go on living. I tell you this against everything you are-

your human heart, your hands passing over the world, gathering and closing, so dry and slow.

Acknowledgements The authors would like to thank Susan Williams' family, Bruce Nyden, Holly Williams, Art Hansen, and Kaitlin Williams Hansen for their input. A special heartfelt thanks, as they suffer the loss that we all feel and more. Deedee Shideler and Tessa Hill were very helpful. Staff and students at the UC Davis and Coastal Marine Sciences Institute and the Bodega Marine Laboratory organized a memorial for Susan, which allowed many of the co-authors an opportunity to gather materials used to generate this paper. In addition, we thank them for establishing a Susan Lynn Williams Memorial Fund. An anonymous reviewer made many useful editorial comments.

Open Access This article is licensed under a Creative Commons Attribution 4.0 International License, which permits use, sharing, adaptation, distribution and reproduction in any medium or format, as long as you give appropriate credit to the original author(s) and the source, provide a link to the Creative Commons licence, and indicate if changes were made. The images or other third party material in this article are included 
in the article's Creative Commons licence, unless indicated otherwise in a credit line to the material. If material is not included in the article's Creative Commons licence and your intended use is not permitted by statutory regulation or exceeds the permitted use, you will need to obtain permission directly from the copyright holder. To view a copy of this licence, visit http://creativecommons.org/licenses/by/4.0/.

\section{References}

Boyer, E.L. 1990. Scholarship reconsidered: Priorities of the professoriate. Special report, Carnegie Foundation for the Advancement of Teaching. New York: Jossey-Bass. pp 147.

Carpenter, R.C., and S.L. Williams. 1993. Effects of algal turf canopy height and microscale topography on flow speed profiles in a coral forereef environment. Limnology and Oceanography 38 (3): 687-694.

Carpenter, R.C., and S.L. Williams. 2007. Mass transfer limitation of photosynthesis of coral reef algal turfs. Marine Biology 151 (2): 435-450.

Cong. Rec. E737 (daily ed. Mary 25, 2018) (Statement of Rep. Jared Huffman of California).

Cowper, Williams S. 1977. The drift algae community of seagrass beds in Redfish Bay, Texas. Contributions in Marine Science 31: 125-132.

Heck, K.L., Jr., T.J.B. Carruthers, C.M. Duarte, A.R. Hughes, G. Kendrick, R.J. Orth, and S. Williams. 2008. Trophic transfers from seagrass meadows subsidize diverse marine and terrestrial consumers. Ecosystems 11: 1198-1210.

Hughes, A.R., R.C. Hanley, J.E. Byers, J.H. Grabowski, J.C. Malek, M.F. Piehler, and D.L. Kimbro. 2017. Genetic by environmental variation but no local adaptation in oysters (Crassostrea virginia). Ecology and Evolution 2017 (7): 697-709

Johnson, M., S.L. Williams, C.H. Lieberman, and A. Solbak. 2003. Changes in the abundance of the seagrasses Zostera marina L. (eelgrass) and Ruppia maritima L. (widgeongrass) in San Diego, California following an El Nino. Estuaries 26 (1): 106-115.

Komoroske, L.M., S.O. Hameed, A.I. Szoboszlai, A.J. Newsom, and S.L. Williams. 2015. A scientist's guide to achieving broader impacts through K-12 STEM collaboration. BioScience 65 (3): 313-322.

Lodge, D.M., S. Williams, H. MacIsaac, K. Hayes, B. Leung, S. Reichard, R.N. Mack, P.B. Moyle, M. Smith, D.A. Andow, J.T. Carlton, and A. McMichael. 2006. Biological invasions: Recommendations for U.S. policy and management. Ecological Applications 16 (6): 2035-2054.

Ojaveer, H., B.S. Galil, J.T. Carlton, H. Alleway, P. Goulletquer, M. Lehtiniemi, A. Marchini, W. Miller, A. Occhipinti-Ambrogi, M. Peharda, G.M. Ruiz, S.L. Williams, and A. Zaiko. 2018. Historical baselines in marine bioinvasions: Implications for policy and management. PLoS One 13 (8): 1-48.

Orth, R.J., T.J.B. Carruthers, W.C. Dennison, C.M. Duarte, J.M. Fourqurean, K.L. Heck Jr., A.R. Hughes, G.A. Kendrick, W.J. Kenworthy, S. Olyarnik, F.T. Short, M. Waycott, and S.L. Williams. 2006. A global crisis for seagrass ecosystems. BioScience 56 (12): 987-996.

Reusch, T.H.B., and S.L. Williams. 1999. Macrophyte canopy structure and the success of an invasive marine bivalve. Oikos 84 (3): 398-416.

Rochman, C.M., A. Tahir, S.L. Williams, D.V. Baxa, R. Lam, J.T. Miller, F.-C. Teh, S. Werorilangi, and S.J. Teh. 2015. Anthropogenic debris in seafood: Plastic debris and fibers from textiles in fish and bivalves sold for human consumption. Nature Scientific Reports 5 (1): 14340.

Suchanek, T.H., S.L. Williams, J.C. Ogden, D.K. Hubbard, and I.P. Gill. 1984. Utilization of shallow-water seagrass detritus by Caribbean deep sea macrofauna: del C-13 evidence. Deep-Sea Research 29: 853-967.

Sur, C., J.M. Abbott, R. Ambo-Rappe, N. Asriani, S.O. Hameed, B.M. Jellison, H.A. Lestari, S.R. Limbong, M. Mandasari, G. Ng, E.V. Satterthwaite, S. Syahid, D. Trockel, W. Umar, and S.L. Williams. 2018. Marine debris on small islands: Insights from an educational outreach program in the Spermonde Archipeligo, Indonesia. Front. Mar. Sci. 16: 1-5

Thayer, G.W., K.A. Bjorndal, J.C. Ogden, S.L. Williams, and J.C. Zieman. 1984. Role of large herbivores in seagrass communities. Estuaries 7 (4): 351-376.

Waycott, M., C.M. Duarte, T.J.B. Carruthers, R.J. Orth, W.C. Dennison, S. Olyarnik, A. Calladine, J.W. Fourqurean, K.L. Heck Jr., A.R. Hughes, G.A. Kendrick, W.J. Kenworthy, F.T. Short, and S.L. Williams. 2009. Accelerating loss of seagrasses across the globe threatens coastal ecosystems. Proceedings of the National Academy of Sciences 106 (30): 12377-12381.

Williams, S.L. 1984. The uptake of sediment ammonium and translocation in the marine green macroalga Caulerpa cupressoides. Limnology and Oceanography 29 (2): 374-379.

Williams, S.L. 1988a. Thalassia testudinum productivity and grazing by green turtles in a highly disturbed seagrass bed. Marine Biology 98 (3): $447-455$.

Williams, S.L. 1988b. Disturbance and recovery of a deep-water Caribbean seagrass bed. Marine Ecology Progress Series 42: 63-71.

Williams, S.L. 1990. Experimental studies of Caribbean seagrass bed development. Ecological Monographs 60 (4): 449-469.

Williams, S.L. 2001. Reduced genetic diversity in eelgrass transplantations affects both individual and population fitness. Ecological Applications 11 (5): 1472-1488.

Williams, S.L. 2007. Introduced species in seagrass ecosystems: Status and concerns. Journal of Experimental Marine Biology and Ecology 350 (1-2): 89-110.

Williams, S.L. 2013. A new collaboration for Indonesia's small islands. Frontiers in Ecology and the Environment 11 (5): 274-275.

Williams, S.L., and R.C. Carpenter. 1988. Nitrogen-limited primary productivity of coral reef algal turfs: Potential contribution of ammonium excretion by Diadema antillarum. Marine Ecology Progress Series 47: 145-152.

Williams, S.L., and R.C. Carpenter. 1990. Photosynthesis/photon flux density relationships among components of coral reef algal turfs. Journal of Phycology 26 (1): 36-40.

Williams, S.L., and C.A. Davis. 1996. Population genetic analyses of transplanted eelgrass (Zostera marina) reveal reduced genetic diversity in southern California. Restoration Ecology 4 (2): 163-180.

Williams, S.L., and W.C. Dennison. 1990. Light availability and diurnal growth of a green macroalga (Caulerpa cupressoides) and a seagrass (Halophila decipiens). Marine Biology 106 (3): 437-443.

Williams, S.L., and T.R. Fisher. 1985. Kinetics of nitrogen-15 labeled ammonium uptake by Caulerpa cupressoides (Chlorophyta). Journal of Phycology 21: 287-296.

Williams, S.L., and E.D. Grosholz. 2002. Preliminary reports from the Caulerpa taxifolia invasion in southern California. Marine Ecology Progress Series 233: 307-310

Williams, S.L., and E.D. Grosholz. 2008. The invasive species challenge in estuarine and coastal environments: Marrying management and science. The H.T. Odum Synthesis. Estuaries and Coasts 31 (1): 3-20.

Williams, S.L., and C.P. McRoy. 1982. Seagrass productivity: The effect of the light on carbon uptake. Aquatic Botany 12: 321-344.

Williams, S.L., and R.J. Orth. 1998. Genetic diversity and structure of natural and transplanted eelgrass populations in the Chesapeake Bay. Estuaries 21 (1): 118-128.

Williams, S.L., and S.L. Schroeder. 2004. Eradication of the invasive seaweed Caulerpa taxifolia by chlorine bleach. Marine Ecology Progress Series 272: 69-76.

Williams, S.L., and J.E. Smith. 2007. A global review of the distribution, taxonomy, and ecological effects of introduced seaweeds. Annual Review of Ecology, Evolution, and Systematics 38 (1): 327-259.

Williams, S.L., S.M. Yarish, and I.P. Gill. 1985. Ammonium distributions, production, and efflux from backreef sediments, St. Croix, U.S. Virgin Islands. Marine Ecology Progress Series 24: 75-81. 
Williams, S.L., R. Ambo-Rappe, C. Sur, J.M. Abbott, and S.R. Limbong. 2017. Species richness accelerates marine ecosystem restoration in the Coral Triangle. Proceedings of the National Academy of Sciences USA 114 (45): 11986-11991.
Williams, S.L., C. Sur, N. Janetski, J.A. Hollarsmith, S. Rapi, L. Barron, S.J. Heatwole, A.M. Yusuf, J. Jompa, and F. Mars. 2019. Largescale coral reef rehabilitation after blast fishing. Restoration Ecology 27 (2): 447-456.

\section{Affiliations}

\section{William C. Dennison ${ }^{1}$ (D) Matthew E. S. Bracken ${ }^{2} \cdot$ Maria Brown $^{3}$ - John F. Bruno ${ }^{4}$ - James T. Carlton ${ }^{5}$. Robert C. Carpenter ${ }^{6} \cdot$ Tim J. B. Carruthers $^{7} \cdot$ Megan N. Dethier ${ }^{8} \cdot$ Carlos M. Duarte $^{9} \cdot$ Thomas R. Fisher $^{1}$. James W. Fourqurean ${ }^{10} \cdot$ Richard K. Grosberg ${ }^{11} \cdot$ Leila J. Hamdan ${ }^{12} \cdot$ Ken L. Heck Jr ${ }^{13}$. Dan J. Howard ${ }^{14}$. A. Randall Hughes ${ }^{15} \cdot$ Brent B. Hughes $^{16}$. Gary A. Kendrick ${ }^{17}$. W. Judson Kenworthy ${ }^{18} \cdot$ Frank Mars $^{19}$. C. Peter McRoy ${ }^{20} \cdot$ Rosamond L. Naylor ${ }^{21}$ • Bruce Nyden ${ }^{22}$ • John C. Ogden ${ }^{23}$ • Suzanne Olyarnik ${ }^{24}$ • Robert J. Orth ${ }^{25}$. Frederick T. Short ${ }^{26}$. Cascade J. B. Sorte ${ }^{2}$ - John J. Stachowicz ${ }^{27}$ • Donald R. Strong ${ }^{28}$. Christine Sur ${ }^{28}$. Michelle Waycott ${ }^{29}$}

1 University of Maryland Center for Environmental Science, 2020 Horns Pt. Rd, Cambridge, MD 21613, USA

2 Department of Ecology and Evolutionary Biology, University of California, Irvine, CA, USA

3 NOAA/NOS/ONMS Gulf of the Farallones National Marine Sanctuary, 991 Marine Drive, The Presidio, San Francisco, CA 94129, USA

4 Department of Marine Sciences, The University of North Carolina at Chapel Hill, Chapel Hill, NC 27599, USA

5 Maritime Studies Program, Williams College-Mystic Seaport, Mystic, CT 06355, USA

6 Department of Biology, California State University, Northridge, CA 91330, USA

7 The Water Institute of the Gulf, 1110 River Road S, Ste. 200, Baton Rouge, LA 70802, USA

8 Megan N. Dethier Friday Harbor Laboratories and Department of Biology, University of Washington, 620 University Road, Friday Harbor, WA 98250, USA

9 Red Sea Research Center, King Abdullah University of Science and Technology, Thuwal, Saudi Arabia

10 Department of Biological Sciences, Florida International University, 11200 SW 8th St, Miami, FL 33199, USA

11 Coastal and Marine Sciences Institute, The University of California, Davis, CA 95616, USA

12 University of Southern Mississippi, Ocean Springs, MS 39564, USA

13 Dauphin Island Sea Lab and Department of Marine Sciences, University of South Alabama, Mobile, AL 36528, USA

14 Cordell Bank National Marine Sanctuary, PO Box 159, Olema, CA 94950, USA
15 Department of Marine and Environmental Sciences, Northeastern University, Nahant, MA 01908, USA

16 Department of Ecology and Evolutionary Biology, University of California Santa Cruz, Santa Cruz, CA 95064, USA

17 The UWA Oceans Institute, University of Western Australia, 35 Stirling Highway, Crawley 6009, Australia

18 Center for Coastal Fisheries and Habitat Research, NCCOS, NOS, NOAA, 101 Pivers Island Rd, Beaufort, NC 28516, USA

19 Mars, Inc., 6885 Elm St., McLean, VA 22101, USA

20 Institute of Marine Science, University of Alaska Fairbanks, Fairbanks, AK 99775, USA

21 Institute for International Studies, Stanford University, Stanford, CA 94305, USA

22 Friday Harbor, USA

23 Integrative Biology, University of South Florida, 190 18th Avenue North, St. Petersburg, FL 33704, USA

24 Bodega Marine Reserve, PO Box 247, Bodega Bay, CA 94923, USA

25 Virginia Institute of Marine Science, College of William and Mary, Gloucester Point, VA 23062, USA

26 Department of Natural Resources and the Environment, Jackson Estuarine Laboratory, University of New Hampshire, 85 Adams Point Road, Durham, NH 03824, USA

27 Department of Evolution and Ecology, The University of California at Davis, Davis, CA 95616, USA

28 Davis, Bodega Marine Laboratory, University of California, Box 247, Bodega Bay, CA 94923, USA

29 Department of Ecology and Evolutionary Biology, School of Biological Sciences, The University of Adelaide, Adelaide, Australia 